\title{
The key factors affecting entrepreneurship: a comparative analysis*
}

\author{
Małgorzata Jabłońska', Joanna Stawska ${ }^{2}$
}

\begin{abstract}
The purpose of the article is to identify the factors determining the rate of entrepreneurship in selected regions of Poland and the Czech Republic, two neighboring countries, within the period 2007 - 2017. This period includes the time of the financial and economic crisis, which could have influenced the entrepreneurship determinants in the regions under study in varying degrees. The differentiation of the impact of selected variables on the entrepreneurship rate had its basis in many elements. To achieve this objective, the following research methods were used: presentation of statistical data, statistical and econometric research methods - the logarithmic panel model with delays. The article also emphasizes the importance of entrepreneurship for the development of a country's economy. Considering the high level of competitiveness in local and global markets, enterprises should pay increasing attention to micro-environment and some regional conditions, because an enterprise depends on these conditions and may influence many of them. The results of the research and thus the contribution and their added value are as follows: an increase in local entrepreneurship is positively transferred to the growth of international entrepreneurship, while $R \& D$ expenditure and average remuneration in the economy are the crucial factors influencing the development of entrepreneurship.
\end{abstract}

Key words: entrepreneurship, SMEs, finance, regional development

JEL classification: R11, R12, F65, M13, L26

\footnotetext{
Received: 08-03-2020; accepted: 03-06-2020

1 Ph.D., Department of Finance and Accounting of SMEs, Faculty of Economics and Sociology, University of Lodz, Rewolucji Street, No 39, 91-214 Lodz, Poland. E-mail: malgorzata. jablonska@uni.lodz.pl. Scientific affiliation: entrepreneurship, financial determinants of entrepreneurship, SMEs. ORCID 0000-0003-1465-8818.

2 Ph.D., Department of Central Banking and Financial Intermediation, Faculty of Economics and Sociology University of Lodz, University of Lodz, Rewolucji Street, No 39, 91-214 Lodz, Poland. Scientific affiliation: enterprises finance, monetary \& fiscal policies. E-mail: joanna. stawska@uni.lodz.pl.ORCID0000-0001-6863-1210.
} 


\section{Introduction}

Entrepreneurship is a multi-faceted phenomenon; hence entrepreneurship research covers numerous academic fields in several different forms. Entrepreneurial opportunities depend on many factors, including the development of private services compared to public service provision and the evolution of the household. Since the end of the eighties of the last century, the balance of services has shifted towards the commercial provision of many services due to several important factors such as privatization, deregulation and a decreasing tax wedge and social security in many countries. Also, the government can influence the resources and skills of individuals by subsidizing information and advisory services, loan guarantees and other direct support systems. In addition, the cultural environment also influences a personal approach to entrepreneurship, which places cultural patterns among the important factors affecting a level of entrepreneurship.

Entrepreneurship is an important element of any economy. In most countries, economic authorities are trying to stimulate the level of entrepreneurship in their countries because enterprises make a significant contribution to economic growth. That is why we decided to examine the impact of selected variables on the degree of entrepreneurship in selected border regions in Poland and the Czech Republic.

The objective of this research is to identify the variables determining entrepreneurship in selected regions of Poland and the Czech Republic. When justifying the selection of these regions, it should be noted that the border areas of Poland and the Czech Republic were selected for analysis for several reasons, namely:

- these are economically close countries;

- border areas of both countries are located in close proximity to each other which gives an opportunity for comparisons in geographically and environmentally similar areas;

- different political conditions allow for objective verification of various, important factors affecting the degree of entrepreneurship in border areas, however, located in two different countries.

The Polish-Czech trade exchange has been growing dynamically since both countries joined the European Union. Poland, apart from Germany and France, is the third strategic trading partner for the Czech Republic. The Czech Republic is also an important partner for Poland in the investment and capital sphere, in particular in such industries as refining, modern technologies, nuclear energy, nanotechnologies and even space research. Cooperation with the Czech Republic can contribute to the growth of innovation and entrepreneurship, given that these countries occupied close places in the rankings describing the ease of doing business in 2019: Poland 40 and the Czech Republic 41. 
What is also worth mentioning is a growing cross-border cooperation on the Polish-Czech border. Dolnośląskie voivodship cooperates with three regions of the Czech Republic: Liberec Region (agreement of 25 February 2003), Pardubice Region (agreement of 22 April 2003) and Hradec Kralovy Region (agreement of 16 October 2003). Opole voivodship conducts international cooperation with the Olomouc Region on the basis of a partnership agreement signed on 9 July 2002. The cooperation of the regions is aimed at tightening relations between the communities on both sides of the border and developing the local economy.

Analyzing the impact of selected indicators on the degree of entrepreneurship in selected regions, we noticed that this impact is very diverse and factors affecting entrepreneurship cover a wide spectrum of disciplines. These are sociological, economic, behavioral, social and other factors. On this basis, we have formed the first hypothesis: the impact of selected variables on the entrepreneurship rate in the discussed regions of Poland and the Czech Republic was diverse and related to many other socio-economic factors. However, we noticed that some of these variables have a stronger impact on entrepreneurship, which is why we have put forward two more hypotheses. The second hypothesis is as follows: $R \& D$ expenditures have an impact on the growth of local entrepreneurship in the surveyed regions; and the third hypothesis: the development of entrepreneurship in the studied regions depends on the value of average remuneration in the regions.

This analysis was carried out to fill the gap on the subject in the literature because according to the current state of the authors' knowledge, such studies have not been conducted.

The structure of the paper is as follows. Section One presents the findings of a review of studies on the theoretical foundations of mechanism shaping entrepreneurship. In section Two, a statistical analysis of selected variables affecting entrepreneurship was carried out. In Section Three, our model of the variables affecting the entrepreneurship rate is introduced. The last section presents conclusions.

\section{Literature review}

The phenomenon of entrepreneurship is widely described in the literature. The studies on regional entrepreneurship have been conducted by such researchers as Brock, Evans, 1989; Hébertand Link, 1989; Dees (1998); Van Praag, (1999); Faris (1999). Many authors have written about entrepreneurship in various aspects. Audretsch, Thurik, Verheul, Wennekers (2002) emphasized that an important determinant of entrepreneurship is a regional policy, which is conducive to the development of entrepreneurship and economic growth. Minniti (1999) wrote about positive aspects of entrepreneurship in the context of self-employment. Similarly, Carree, A.J van Stel, Thurik and Wennekers, (2002) emphasized a 
positive, significant relationship between entrepreneurship and employment growth and economic development. Audretsch and Thurik, (2001, 2004) described the importance of the contribution of knowledge and ideas in the so-called "entrepreneurial economy"; Grilo, Thurik (2004) have expanded the concept of Eclectic Framework describing entrepreneurship, which covers various currents of literature and disciplines. Others like Leković, Berber (2019) proved statistically significant connections between motives of entrepreneurship, innovation or internationalization and the development of enterprises. Entrepreneurship primarily results from the multi-faceted nature of this issue, which goes far beyond the area of economics alone, and is located on the border of many other sciences, including psychology, sociology or economic geography (Hills, Lumpkin, Singh, 1997; Dees, 1998). This is an important feature in the context of seeking entrepreneurship determinants.

In this article, we focus on the approach to enterprise description proposed by Gartner (1988), for whom entrepreneurship is a set of processes related to the emergence of new and the development of existing business entities. In the second approach, developed by Faris (1997), however, entrepreneurship is treated as one of the forms of social behavior and examined from the point of view of the personal characteristics of entrepreneurial individuals. In this case, this definition is not only limited to the economic sphere, but it is extended to aspects related to human activities (except existential ones). This approach is too broad and entrepreneurship is difficult to measure in the context of the research carried out in our work.

The greater the participation of entrepreneurs in the economic life of a country or region, the greater the chances the development of this area. The entrepreneur is focused on perceiving new economic opportunities and further introduces new ideas to the market - according to the Schumpetarian approach (Wennekers and Thurik (1999). The decisions made by the entrepreneur ultimately affect the location, form and use of goods, resources or institutions (Hebert and Link (1989).

One of the first and most important attempts to empirically measure the phenomenon of entrepreneurship was the study undertaken in the late 1990s as part of the Global Entrepreneurship Monitor (GEM) project. This study was conducted at the level of selected countries, assuming that entrepreneurship is expressed through any attempt to start a new venture, such as self-employment, setting up a new business entity or expansion of an existing enterprise (Minniti, 1999). These studies indicate that entrepreneurship is playing an increasingly important role in the global economy and that it makes a significant contribution to economic growth.

Audretsch and Thurik (2001 and 2004) write about moving away from large companies towards small, mainly new companies, which is a significant change, not just a temporary deviation from the main trend. These authors define this new economic period, based less on the traditional contribution of natural 
resources, labor and capital, and more on the input of knowledge and ideas as an "entrepreneurial economy". Paradoxically, the increase in uncertainty creates opportunities for small and young companies, resulting in higher entrepreneurship rates. We note that a higher degree of entrepreneurship is rooted not only in large companies but more often in these smaller, young enterprises.

In recent years, along with competitiveness and innovation, entrepreneurship has become one of the most important issues related to the analysis of economic growth processes. One of the factors that increases competitiveness and, consequently, the increase in entrepreneurship of a given economy is the increase in innovation (Dziuba, 2014). Entrepreneurship is treated as an important indicator of this growth, as evidenced by the role ascribed to entrepreneurship development in creating regional policy at the national and regional level (Sechster, 1999; Jabłońska, Stawska, Czechowska 2019). In addition, it is worth noting a strong link between entrepreneurship and innovation (Hills, Lumpkin, Singh, 1997). Over the past two decades, entrepreneurship has become a key point of interest of economic politicians across Europe. Moderate economic growth combined with high unemployment stimulated expectations regarding the potential of entrepreneurship as a source of creating new jobs and economic growth (Audretsch, Thurik, 2000; Carree, Thurik, 2002). This is especially visible in the case of industries looking for innovations, such as green enterprise among the textile sector (Burzyńska, Jabłońska, Dziuba, 2018).

The phenomenon of emerging small businesses is more than ever seen as an entrepreneurial tool that not only contributes to employment and social and political stability, but also contributes to innovation and increased competitiveness. Many economists, based on econometric evidence, suggest that entrepreneurship is a determinant of economic growth (Audretsch and Thurik, 2000; Audretsch, et.al. 2002; Carree and Thurik, 1999; Carree, et.al. 2002; Audretsch, Carree and Thurik, 2002). Some authors such as Audretsch et. al. (2002) believe that due to the lack of entrepreneurship, economies would incur costs associated with lost economic growth. However, the positive and statistically significant relationship between entrepreneurship and economic growth has been undeniably verified in a wide spectrum of observation units, including a plant, enterprise, industry, region and country. In the face of growing concerns related to unemployment, employment, growth and international competitiveness in global markets, decision-makers have responded to these phenomena with a desire to create new companies, see Reynolds et. al. (2000). Initially, European decision-makers relatively slowly recognized these links between entrepreneurship and economic growth, but since the mid1990s this view has spread quickly (European Commission, 2000).

Zoltan et al. (2012) on the basis of a cross-sectional panel of time series based on a country-specific measure of entrepreneurship, noticed that the activity of enterprises in fact positively contributes to economic growth. In addition, they emphasize 
that countries with a higher degree of entrepreneurship are consistently showing a higher level of economic growth. The results indicate the importance of a country's policy that not only promotes investment in R\&D but also takes into account the role of the intermediation mechanism such as entrepreneurship.

The OECD emphasizes that self-employment is also an important source of entrepreneurship and growth especially for small businesses - with the potential to increase employment in the long run (OECD, 2000).

In another study conducted in six countries from Central and Eastern Europe, an exploratory sample of 12,027 respondents and 457 fast-growing entrepreneurs was created. It was noted that the motives of entrepreneurship, innovation and internationalization of the new venture have a statistically significant connection with the rapid growth of enterprises in the studied region of Southeastern Europe (Leković, Berber, 2019).

Grilo, Thurik (2004) describe a study that uses the Eclectic Framework which explains entrepreneurship covering various streams of literature and various disciplines. The Eclectic Framework combines factors that shape the demand for entrepreneurship on the one hand, and influence the supply of entrepreneurs on the other. This enables an insight into the role of public policy defining the channels through which the demand or supply of entrepreneurship can be shifted. The study used polynomial logit using data from 15 EU Member States, Norway, Iceland, Liechtenstein and the US to determine the impact of demographic and other variables on different levels of entrepreneurial involvement. The data used came from two Eurobarometer surveys on entrepreneurship $(2003,2004)$ with over 20,000 observations. Among explanatory variables, in addition to demographic variables, the survey examined such characteristics as how the respondents perceived administrative complexities, availability of financial support, approximate risk tolerance, respondents' preferences for self-employment and country-specific effects. One of the surprising results was that the perception of the lack of financial support does not have a discriminatory effect on various ways of entrepreneurial involvement.

Additionally, the tax system is a good example of the entrepreneurship determinant, which is very diverse in different countries. The tax system may be favorable to entrepreneurship or inhibiting entrepreneurship. Ambiguously written regulations, rules, frequent changes in tax law, expiration clauses and various levels of regional and national taxation significantly affect the degree of entrepreneurship of a given country or region. In addition, immigration policy and regional development policy dealing with (sub) urbanization processes affect the age composition and dispersion of employees in a given area, respectively (OECD, 1998).

Audretsch, Thurik et al. (2002) describe the scope of determinants that explain the level of entrepreneurship, including economic and social factors. In addition, they also list political factors that may also affect the level of entrepreneurship. Government can 
influence entrepreneurship in various ways, e.g. directly through specific measures and indirectly through general measures. For example, by establishing a competitiveness policy, the government can influence the market structure and indirectly, a number and type of entrepreneurial opportunities. Generally, the level of entrepreneurship in a given country can be explained by making a distinction between the supply side (labor market perspective) and the demand side (product market perspective; market capacity) of entrepreneurship. Similarly, entrepreneurship determinants can also be studied according to a certain level of analysis. This means that a distinction can be made between micro-, meso- and macro-levels of entrepreneurship. The subjects of research related to these levels of analysis are, respectively: individual entrepreneur or business, industry sectors and the national economy. Research at the micro-level focuses on the decision-making process of individuals and on the people's motives for self-employment. Research on the decisions of people taking up employment or selfemployment mainly focuses on personal factors such as psychological characteristics, formal education and other skills, financial assets, family background and previous professional experience. Research at the meso-level of entrepreneurship often focuses on market-specific entrepreneurship determinants, such as profit opportunities and entry and exit opportunities. In turn, the macro perspective focuses on a number of environmental factors, such as technological, economic and cultural variables, as well as government regulations.

In the literature, the most common measures of entrepreneurship include, the number of active enterprises per 1000 inhabitants; the number of employed persons per one active entity; the number of employed persons in active enterprises per 1,000 inhabitants; the amount of revenues per one employee; cost level indicator; average salary level; the size of investment outlays per one enterprise or the growth rate of start-ups. In this study, the growth rate of startups was used as a measure of entrepreneurship (Gries, Naude, 2009). Based on the literature, we made a selection in our study of determinants that, in our opinion, significantly affects the degree of entrepreneurship in the examined border regions of Poland and the Czech Republic.

\section{Methodology}

The dynamics of socio-economic processes forces the use of modern knowledge, reliably and faithfully reflects the essence of occurring phenomena and processes. Undertaking analysis of the course of entrepreneurship changes in regions over time, the use of econometric modeling methods that provide objective, accurate and comprehensive knowledge of the studied reality is deeply justified.

The econometric methods used, in particular the logarithmic panel model with delays, in the study is an irreplaceable source of instrumental knowledge necessary 
for application in current social, economic, technical and educational policy, on the other hand in planning and forecasting the development of entrepreneurship in Polish regions and the Czech Republic. What is more, it is new compared to the regional entrepreneurship research conducted so far, which largely focuses on qualitative research. In their empirical research on entrepreneurial phenomena, researchers used data sets such as the Panel Study of Entrepreneurial Dynamics (Carter, et. al. 2003; Davidsson, 2003; Liao and Welsch, 2008, Curtin and Reynolds 2018) and the Comprehensive Australian Study of Entrepreneurial Emergence (Davidsson, Steffens and Gordon, 2011).

According to the latest achievements in the field of entrepreneurship, there is a growing interest in developing methods that will show the theoretical and practical significance of the results developed, including quantitative research. In the research conducted so far on the development of the phenomenon of regional entrepreneurship, a linear econometric model was used using the classical least squares method (KMNK) (Walczak, Żołądkiewicz, 2015) or describing panel data (Meyer, 2017). The premise for use in the study of a dynamic panel model using delayed variables is the specifics of the study. Entrepreneurs often decide to develop or discontinue operations based on previous events.

The general form of such a model can therefore be written as:

log_business_indic $c_{i t}=\alpha_{0}+\beta_{1} \cdot \log$ _income_munici $i_{i t}+$

$+\beta_{2} \cdot \log _{-}$average_salary ${ }_{i t}+\beta_{3} \cdot \log _{-}$inw_exp ${ }_{i t}+\beta_{4} \cdot \log _{-} \operatorname{social}_{-}$benefit $s_{i t}+$

$+\beta_{5} \cdot \log _{-}$unepmit $+\beta_{6} \cdot \log \_$exp_B $+R_{i t}+u_{i t}$

where:

- parameters $\beta_{k}$ mean the elasticity of the entrepreneurship rate relative to the $\mathrm{k}$-th model explanatory variable, so they are interpreted as a relative change in the entrepreneurship rate as a result of a $1 \%$ increase in the $\mathrm{k}$-th model explanatory variable,

The random component is decomposed into two components:

$-\alpha_{i}$ a component that reflects the group effect (fixed effect - FE or random effect -RE, depending on the Hausman test results) and the appropriate random component $v_{i t}$

$$
\left(v_{i t} \sim N\left(0, \sigma_{v}^{2}\right) .\right.
$$

In dynamic terms, the value of the independent variable depends on its lagged (by one period) value and on the values of the explanatory variables included in the model. The process of estimating a dynamic panel model is most often carried 
out using the generalized method of moments (GMM), after first transforming the model to the form of the first differences. The model after transforming into the first differences model has the form (Bond, 2002; Ahmed, et al. 2014):

$$
\Delta y_{i t}=\gamma \Delta y_{t-1}+\left(\Delta \mathbf{x}_{t}^{T}\right) \hat{\mathbf{a}}+\Delta v_{t}
$$

This removes the fixed effects, specific to individual objects from the model. Due to the fact that the lagged dependent variable is included in the model, the phenomenon of first-order autocorrelation often occurs, because if the random component, i.e. $\varepsilon_{i t}$ is independent, their first differences are subject to the first-order autocorrelation scheme. The occurrence of second-order autocorrelation in this model would consequently lead to failure to meet moment conditions and incompatibility of the estimator, which would mean the wrong selection of instruments used in the model estimation process. For this reason, it is extremely important to test whether the dynamic model has second-order autocorrelation, i.e. AR (2) (Brañas-Garza et al., 2011; Bun, Sarafidis, 2013).

\section{Empirical data and analysis}

Based on the results of theoretical research and availability of specific statistical data, variables that reflect various aspects of entrepreneurship development in the Polish and Czech border regions were specified. Entrepreneurship at the voivodship level in Poland, (the regions in the Czech Republic), was defined by means of an indicator specifying the number of registered enterprises of the MSME (Medium, Small and Micro Entreprices) sector per 100 people at working age. Analyzing the average value of this indicator in the years 2007-2017 (see Figure 1) it can be stated that in the Czech regions, covered by the survey, the average value of this indicator significantly exceeded the Polish values. In the Czech Republic, the entrepreneurship rate was around 16 companies per 100 people at working age, while in Poland the value of this indicator slightly exceeded 10. The Liberec Region (average 18.63) turned out to be the most entrepreneurial among the examined regions, while the Silesian Voivodship turned out to be the least enterpreneurial. (average 9.70).

The purpose of the econometric model, constructed for the study, is to describe the relationship between the entrepreneurship rate, which determines the number of enterprises per number of working-age population - and explanatory variables. The set of explanatory variables considered here is not complete and in no case can be considered closed. Due to the difficult access to data and the assumed time horizon, the work was based on the analysis of selected factors only, largely of a financial nature, which may foster (or inhibit) the development of entrepreneurship. 
Figure 1: Entrepreneurship rate in 2007-2017 in the analyzed regions.

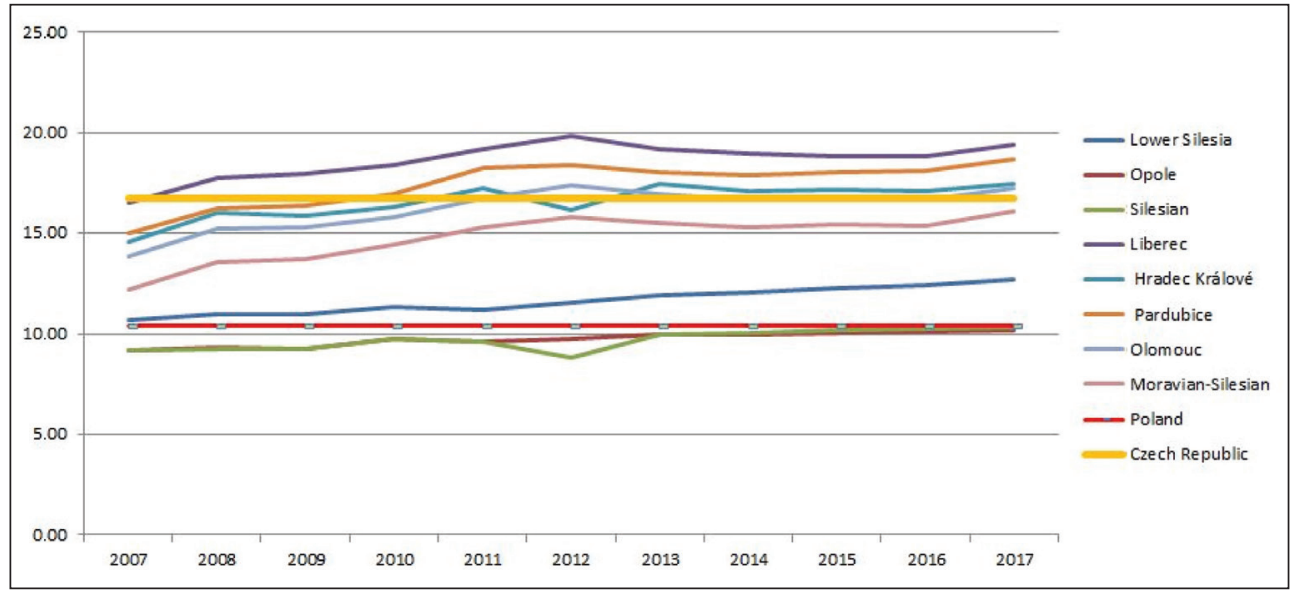

Note: Authors' calculations based on Local Data Bank, Statistics Poland [www.bdl.gov.pl] and Czech Statistical Office [https://www.czso.cz]

Simplification of reality in econometric models involves taking into account only the most important factors (variables) affecting the dependent variable. In addition to the variables used in the cross-sectional time-series models in the study, specific non-measurable, constant over time and object-specific factors, called group effects and/or non-measurable but period-specific factors called time effects, were also taken into account (see: Baltagi, 2005). The variables are stationary, LLC tests performed it. For explanatory variables in the model it was decided to choose the following set:

- inw_exp - share of municipal investment expenditure in total expenditure (\%) positively correlated with the dependent variable in the model;

- average_salary - average gross monthly salary in the enterprise sector (constant prices in euros) - positively correlated with the dependent variable in the model;

- unepm _ share of registered unemployed persons in the number of working age population (\%) - positively correlated with the dependent variable in the model;

- income munici - total revenues of municipalities per capita (constant prices in euros) - positively correlated with the dependent variable in the model;

- social_benefits - average social benefits in the economy (constant prices in euros) - negatively correlated with the dependent variable in the model;

- exp_B+R - expenditure on R\&D in the economy per capita (constant prices in euros) - positively correlated with the dependent variable in the model; 
Małgorzata Jabłońska, Joanna Stawska • The key factors affecting entrepreneurship...

- business_indic - entrepreneurship indicator - the number of active enterprises per 100 people at working age.

The table below provides basic descriptive statistics of variables that were selected for the study.

The table presents the values of basic descriptive statistics for the above variables (mean, median, standard deviation, coefficient of variation, coefficient of skewness). These values were determined on the basis of the values of these variables collected at the the municipality level in 2007-2017. Based on the results obtained, the following drawn conclusions are as follows:

Table 1: Values of basic descriptive statistics for Polish and Czech regions covered by the survey

\begin{tabular}{|c|c|c|c|c|c|}
\hline \multicolumn{6}{|c|}{ Polish regions } \\
\hline & average & median & $\begin{array}{l}\text { standard } \\
\text { deviation }\end{array}$ & $\begin{array}{c}\text { Coefficient of } \\
\text { variation }\end{array}$ & $\begin{array}{c}\text { Coefficient of } \\
\text { skewness }\end{array}$ \\
\hline income_munici & $1,276.70$ & $1,225.60$ & 251.71 & 0.197 & 0.558 \\
\hline average_salary & 892.92 & 894.53 & 108.16 & 0.121 & 0.027 \\
\hline inw_exp & 0.172 & 0.179 & 0.040 & 0.231 & -0.291 \\
\hline social_benefits & 0.031 & 0.032 & 0.0036 & 0.115 & -0.296 \\
\hline unepm_ & 0.062 & 0.062 & 0.013 & 0.210 & -0.293 \\
\hline exp_B $+R$ & 50.65 & 47.08 & 28.98 & 0.572 & 0.551 \\
\hline business_indic & 10.36 & 10.08 & 1.062 & 0.102 & 0.721 \\
\hline \multicolumn{6}{|c|}{ Czech regions } \\
\hline & mean & median & $\begin{array}{c}\text { standard } \\
\text { deviation }\end{array}$ & $\begin{array}{c}\text { Coefficient of } \\
\text { variation }\end{array}$ & $\begin{array}{c}\text { Coefficient of } \\
\text { skewness }\end{array}$ \\
\hline income_munici & 999.03 & $1,000.80$ & 114.43 & 0.114 & 0.0665 \\
\hline average_salary & 752.36 & 752.11 & 35.388 & 0.047 & -0.142 \\
\hline inw_exp & 0.255 & 0.258 & 0.0472 & 0.184 & -0.078 \\
\hline social_benefits & 155.72 & 163.68 & 44.128 & 0.283 & -0.059 \\
\hline unepm & 0.0611 & 0.051 & 0.026 & 0.426 & 1.21 \\
\hline exp_B+R & 161.25 & 152.41 & 18.228 & 0.299 & 0.597 \\
\hline business_indic & 16.74 & 16.70 & 1.63 & 0.097 & -0.361 \\
\hline
\end{tabular}

Note: Author's calculations based on Local Data Bank, Statistics Poland [www.bdl.gov.pl] and Czech Statistical Office [https://www.czso.cz]

1. The vast majority of the analyzed variables are characterized by a similar average level in Poland compared to the Czech regions selected for the survey. Significant 
differences are evident when comparing the aforementioned entrepreneurship rate (the average for Polish regions in the years 2007 - 2017 was 10.36 companies per 100 people at working age, while in the Czech regions the average value of this indicator was slightly higher than 16 companies per 100 people at working age. Significant differences are evident in the following variables: social benefits (in Poland 0.031 euros per person and in the Czech Republic 155 euros) and expenditure on R\&D (in Poland 50 euros per person and in the Czech Republic 161 euros per person).

2. The variation in most of the examined features is moderate (values of coefficients of variation range between $10 \%$ and 57\% in Poland and $4 \%$ and $42 \%$ in the Czech Republic). It should be noted that in the Czech Republic the variation of salaries is the smallest ( $4 \%$ vs. $12 \%$ in Poland), and the variation of the share of the unemployed is the highest ( $42 \%$ vs. $21 \%$ in Poland). In Poland, in turn, the most varied variable is expenditure on R\&D - approx. 57\%. In the Czech Republic this parameter also belongs to one of the most varied ones (30\%).

3. The variables examined include those characterized by right - and left - sided asymmetry. Right - sided asymmetry means that the regions under study have below-average feature values. Both in Poland and the Czech Republic these are municipal revenues and R\&D expenses. The opposite situation occurs in the case of a variable which specifies the amount of investment expenditure or social benefits.

In the next stage of the study, an attempt was made to construct an econometric model that explains changes in the rate of entrepreneurship. Factors that may potentially affect changes in the rate of entrepreneurship include (in accordance with the purpose of the work) primary factors describing the financial condition of municipalities located in Poland in the border area with the Czech Republic and in municipalities bordering Poland located on the Czech side. For comparison, the study was carried out in three variants (for municipalities located in the Lower Silesian, Opole and Silesian voivodships, for Czech municipalities that are located in the regions of Liberec, Hradec Králové, Pardubice, Olomouc and Moravian-Silesian, and for all groups of regions). Data for the model cover the years 2007-2017. Further variants were constructed separately for municipalities of Polish provinces and municipalities located in the Czech Republic. The loglinear (power) form of the model was adopted, which was estimated based on panel data, taking into account group effects (fixed effects - FE or random effects - RE), differentiating individual objects (municipalities).

The table below presents the results of the estimation of dynamic panel models, in which the logarithm of the entrepreneurship index is the dependent variable (the results of the two - according to the authors - the best variants are presented). The standard error of residuals is $\mathrm{Vu} \%$ of the average level of the independent variable and is less than $10 \%$, which is a sufficient adjustment of the model to empirical data (in each of the presented variants it is less than $10 \%$ ). 
Table 2: Dynamic panel estimation using 64 observations (eight regions - 3 Polish and 5 Czech regions). Dependent variable (Y): Log_business_indic

\begin{tabular}{|c|c|c|}
\hline Variables & Basic variant & Improved variant \\
\hline log_business_indic $(-1)$ & $\begin{array}{r}0.063 \\
(1.352) \\
\end{array}$ & $\begin{array}{r}0.067 * * \\
(2.193) \\
\end{array}$ \\
\hline log_business_indic (-2) & $\begin{array}{r}-0.054 \\
(-0.6844)\end{array}$ & $\begin{array}{r}-0.0581 * * \\
(-2.128)\end{array}$ \\
\hline const & $\begin{array}{r}0.0032 \\
(0.7195) \\
\end{array}$ & $\begin{array}{r}0.003364 \\
(0.8779)\end{array}$ \\
\hline log_income_munici & $\begin{array}{r}-0.0169 \\
(-0.0769)\end{array}$ & \\
\hline log_average_salary & $\begin{array}{l}-0.7493 \\
(-1.398)\end{array}$ & $\begin{array}{r}-0.7776 * * * \\
(-4.235)\end{array}$ \\
\hline log_inw_exp & $\begin{array}{r}-0.1312 * * * \\
(-3.727)) \\
\end{array}$ & $\begin{array}{r}-0.13113 * * * * \\
(-3.859) \\
\end{array}$ \\
\hline log_social_benefits & $\begin{array}{r}0.0216 * * * \\
(2.869)\end{array}$ & $\begin{array}{r}0.0216 * * * \\
(3.711) \\
\end{array}$ \\
\hline $\log _{-}$unepm & $\begin{array}{r}-0.1149 * * * \\
(-6.009)\end{array}$ & $\begin{array}{r}-0.1184 * * * \\
(-7.786)\end{array}$ \\
\hline $\log _{-}$exp_B $+\mathrm{R}$ & $\begin{array}{r}0.1609 * * * \\
(8.707) \\
\end{array}$ & $\begin{array}{r}0.1592 * * * \\
(8.783) \\
\end{array}$ \\
\hline Residual sum of squares & 0.446452 & 0.442266 \\
\hline Residual standard error & 0.090096 & 0.08869 \\
\hline AR (2) test & $\begin{array}{c}\mathrm{z}=-1.61318[0.1067] \\
\text { No autocorrelation } \\
\mathrm{p}>0.05\end{array}$ & $\begin{array}{c}\mathrm{z}=-1.52006[0.1285] \\
\text { No autocorrelation } \\
\mathrm{p}>0.05\end{array}$ \\
\hline
\end{tabular}

Note: $* \mathrm{P}<0.1,{ }^{* *} \mathrm{p}<0.05,{ }^{* * *} \mathrm{p}<0.01$. Values for t-Student statistics are given in round brackets. Source: Authors' calculations

Taking into account all regions selected for the study, it turned out that the dependent variable, i.e. the rate of entrepreneurship, was influenced by the explanatory variables, expenditure on investments in municipalities, expenditure on social benefits, the share of the unemployed in the number of working age population and expenditure on R\&D. The variable describing the income of municipalities, which has no impact on the development of the described phenomenon, was eliminated from the group of factors that stimulate the formation of the entrepreneurship measured by the rate of involvement of people at working age in running their own business. 
Table 3: Dynamic panel estimation using 45 observations (5 Czech observations). Dependent variable (Y): Log_business_indic

\begin{tabular}{|c|c|c|}
\hline Variables & Basic variant & Improved variant \\
\hline log_business_indic $(-1)$ & $\begin{array}{r}-0.0800 \\
(-0.9151)\end{array}$ & $\begin{array}{r}-0.1524 * * * \\
(-3.023)\end{array}$ \\
\hline const & $\begin{array}{r}0.0072 * \\
(1.876)\end{array}$ & $\begin{array}{r}0.00693 * * \\
(2.004) \\
\end{array}$ \\
\hline log_income_munici & $\begin{array}{r}-0.1040 * * \\
(-2.539)\end{array}$ & $\begin{array}{r}-0.1470 * * \\
(-2.497)\end{array}$ \\
\hline $\log$ _average_salary & $\begin{array}{r}0.5242 * * * \\
(3.733) \\
\end{array}$ & $\begin{array}{r}0.6959 * * * \\
(4.551) \\
\end{array}$ \\
\hline log_inw_exp & $\begin{array}{l}-0.05593 \\
(-0.9471)\end{array}$ & \\
\hline log_social_benefits & $\begin{array}{l}0.1034 \\
(1.355) \\
\end{array}$ & $\begin{array}{r}0.09877 \\
(1.419) \\
\end{array}$ \\
\hline $\log _{-}$unepm_ & $\begin{array}{r}-0.09768 * * \\
(-2.012) \\
\end{array}$ & $\begin{array}{r}-0.0886 * \\
(-1.888) \\
\end{array}$ \\
\hline $\log _{-}$exp_B $+R$ & $\begin{array}{r}0.09659 * * * \\
(6.453)\end{array}$ & $\begin{array}{r}0.1041 * * * \\
(3.599)\end{array}$ \\
\hline Residual sum of squares & 0.128423 & 0.117416 \\
\hline Residual standard error & 0.058914 & 0.055587 \\
\hline $\mathrm{AR}(2)$ test & $\begin{array}{c}\mathrm{z}=-0.912349[0.3616] \\
\text { No autocorrelation } \\
\mathrm{p}>0.05\end{array}$ & $\begin{array}{c}\mathrm{z}=-0.944709[0.3448] \\
\text { No autocorrelation } \\
\mathrm{p}>0.05\end{array}$ \\
\hline
\end{tabular}

Note: $* \mathrm{p}<0.1,{ }^{* *} \mathrm{p}<0.05,{ }^{* * *} \mathrm{p}<0.01$. Values for $\mathrm{t}$-Student statistics are given in round brackets.

Note: Authors' calculations

Conducting a more detailed analysis that explains the impact of individual explanatory variables on the rate of entrepreneurship in the studied regions, taking into account their location and the environment in which they operate, will indicate the main differences and similarities between the regions. The table above presents the estimated variants of the model, that describes the impact of explanatory variables on the dependent variable (entrepreneurship rate) in the regions of Liberec, Hradec Králové, Pardubice, Olomouc and Moravian - Silesian. The study showed that the current value of entrepreneurship rate in the years 2007-2017 in the Czech regions was determined primarily by expenditure on $R \& D$ and average wages in the economy (both variables are characterized by a positive impact on the entrepreneurship rate) and the lagged dependent variable. Importantly, the variables describing the value of social benefits and the share of investment expenditure turned out to be irrelevant to the development of the described phenomenon, which clearly distinguishes this variant of the model from the one constructed for the whole sample. 
Table 4: Dynamic panel estimation using 27 observations (3 Polish observations). Dependent variable (Y): Log_business_indic

\begin{tabular}{|c|c|c|}
\hline Variables & Basic variant & Improved variant \\
\hline $\log _{-}$business_indic $(-1)$ & $\begin{array}{r}0.00331 \\
(0.02531) \\
\end{array}$ & $\begin{array}{l}-0.004391 \\
(-0.03153)\end{array}$ \\
\hline const & $\begin{array}{c}0.00050 \\
(0.1676)\end{array}$ & $\begin{array}{r}0.001195 \\
(0.6211)\end{array}$ \\
\hline log_income_munici & $\begin{array}{r}0.6513 * * * \\
(5.175)\end{array}$ & $\begin{array}{r}0.6610 * * * \\
(4.801)\end{array}$ \\
\hline $\log _{\text {_ average_salary }}$ & $\begin{array}{r}-0.6931 * * * \\
(-6.592) \\
\end{array}$ & $\begin{array}{r}-0.7279 * * * \\
(-6.475) \\
\end{array}$ \\
\hline log_inw_exp & $\begin{array}{r}-0.0225 \\
(-0.8467)\end{array}$ & \\
\hline log_social_benefits & $\begin{array}{r}0.431 * * * \\
(10.25) \\
\end{array}$ & $\begin{array}{r}0.4393 * * * \\
(8.214) \\
\end{array}$ \\
\hline $\log _{-}$unepm_ & $\begin{array}{r}0.1841 * * * \\
(21.90) \\
\end{array}$ & $\begin{array}{r}0.1750^{* * *} \\
(16.02) \\
\end{array}$ \\
\hline $\log \_$exp_B $+R$ & $\begin{array}{r}0.07294 * * * \\
(6.036)\end{array}$ & $\begin{array}{r}0.0692 * * * \\
(9.617)\end{array}$ \\
\hline Residual sum of squares & 0.103518 & 0.103553 \\
\hline Residual standard error & 0.073813 & 0.071956 \\
\hline AR (2) test & $\begin{array}{c}\mathrm{z}=-912282[0.3616] \\
\text { No autocorrelation } \\
\mathrm{p}>0.05\end{array}$ & $\begin{array}{c}\mathrm{z}=-0.923612[0.3557] \\
\text { No autocorrelation } \\
\mathrm{p}>0.05\end{array}$ \\
\hline
\end{tabular}

Note: ${ }^{*} \mathrm{p}<0.1, * * \mathrm{p}<0.05, * * *<\mathrm{p} 0.01$. Values for t-Student statistics are given in round brackets.

Note: Authors' calculations

The last version of the study concerns the estimation of variables affecting the rate of entrepreneurship in the Polish regions bordering the Czech Republic. Based on the collected data, it turned out that the following factors had a strong impact on the development of entrepreneurship, municipal incomes, average wages in the economy, the level of social benefits, the share of the unemployed and expenditure on $R \& D$. The share of investment expenditure and the lagged dependent variable, are the variables that do not affect the dependent variable.

\section{Results and discussions}

Entrepreneurship is a very important economic category, especially from the point of view of the development of economies. Entrepreneurship research is largely based on an analysis of the SME sector, which plays a key role in the country's economic development. The conducted empirical study on factors influencing the development of entrepreneurship in Poland and the Czech Republic showed numerous differences and similarities. 
In all estimated variants of the model, the impact of $R \& D$ expenses and average remuneration in the economy turned out to be significant. However, the impact of these variables varies from one region to another. In the border regions of the Czech Republic, the flexibility of the entrepreneurship rate in the current period relative to the expenditure on $R \& D$ variable ranges between 0.11 and 0.12 , while in the examined regions of Poland a weaker effect was noted - here the flexibility does not exceed 0.10 . This slightly different level of flexibility is related to the innovation of these two countries. Although both Poland and the Czech Republic were among the so-called moderate innovators, there are significant differences in expenditure on innovation, in the number of implementations and patents, etc. (SII index for 2016 for Poland was 54.8 and for the Czech Republic 84.4 (European Scoreboard, 2017)). Enterprises located in the Czech Republic are focused on innovation and make their growth dependent on it, hence the flexibility of this variable in relation to the rate of entrepreneurship in these regions is higher. The level of average wages in the economy also has a different, but significantly significant impact on the entrepreneurship rate, both in relation to the entire sample and the separately examined regions. In the examined regions of the Czech Republic, the impact of this explanatory variable on the entrepreneurship rate was positive. This demonstrates that people are motivated to start their own business; they are not forced to do so by the lack of a job. In Poland, however, we have the opposite effect. The study showed that in the years 2007-2017 the impact of the average level of wages in the economy negatively affected the development of entrepreneurship. The collected data indicate that a significant increase in wages in the Polish economy took place after 2010, and wages were at a level comparable with wages in the Czech regions studied, and even higher. It can therefore be concluded that running one's own business at a certain level of remuneration in the economy is not attractive, therefore, the level of remuneration for these regions (saturated with a large number of micro enterprises) had a negative impact on the creation of new companies.

In the estimated variants of the model, the influence of the lagged dependent variable on its current value turned out to be different. In the regions of the Czech Republic studied, the impact of this variable turned out to be statistically and negatively significant (the elasticity of the entrepreneurship rate in the current period relative to the entrepreneurship rate from the previous period ranges between -0.08 and -0.15 ), while in Polish regions this variable had no real impact on entrepreneurship. Regions located on the Polish side belong to the most saturated voivodeships in terms of entrepreneurship, hence the rate of entrepreneurship in the current period does not react under the influence of changes in the rate of entrepreneurship from the previous period.

The impact of the variable describing social benefits on the entrepreneurship rate is an interesting phenomenon. In the provinces located on the Czech side this variable 
turned out to be statistically insignificant. This confirms the hypothesis about the positive motivation to start one's own business. In Polish regions, however, this variable strongly and positively affects the rate of entrepreneurship (flexibility of $0.4)$.

In the examined regions in Poland and the Czech Republic, the impact of investment expenditure on the entrepreneurship rate was insignificant. On the one hand, this may be due to the fact that the short-term effects of European integration and, at the same time, integration of regions, often do not reflect investment expenditure incurred at the initial stage of convergence. This particularly applies to the specifics of investment expenditure on the development of entrepreneurship. Expenditure incurred in the financial perspectives 2007-2013 and 2014-2017 for investment purposes such as "business-related" infrastructure should bring definite effects in the long run. Therefore, in the initial phase, the increase in expenses was not directly felt by entrepreneurs. On the other hand, however, the decreasing size of the population due to migration means that the most entrepreneurial and talented inhabitants of a given region often fail to recognize the benefits of stimulating entrepreneurship in the initial phase of European integration, and leave the region and emigrate to more developed EU regions.

\section{Conclusions}

The article attempts to identify variables determining entrepreneurship in selected regions of Poland and the Czech Republic. In addition, it was assumed that the impact of selected variables on the entrepreneurship rate in the discussed regions of Poland and the Czech Republic was diverse and related to many other socioeconomic factors.

In the study, in which all the selected regions were included, it turned out that the entrepreneurship rate as the independent variable was significantly affected by the following variables, expenditure on investments in municipalities, expenditure on social benefits, the share of the unemployed in the number of people of working age and expenditure on $R \& D$.

On the other hand, in the model in which only Czech regions were taken into account, the current value of entrepreneurship rate was mostly affected by expenditure on R\&D as well as by average remuneration in the economy and the lagged independent variable. However, municipal incomes and the share of the unemployed in the number of people of working age also had a significant impact on the entrepreneurship rate. On the other hand, the results of the study, conducted for Polish regions indicate that the following variables had a significant impact on the entrepreneurship in the years 2007-2017, municipal incomes, average wages in the economy, the level of social benefits, the share of the unemployed and 
expenditure on R\&D. It must be noted that in the study conducted for all regions, as well as the Czech and Polish regions, only expenditure on R\&D and average remuneration in the economy occurred in all the examined groups.

The differentiation of the impact of selected variables on the entrepreneurship rate in Poland and the Czech Republic had its basis in many elements that influenced selected determinants of entrepreneurship. Such significant differentiating factors include, cultural conditions, the structure of the business sector, market legislation, tax environment, and social security systems. In addition, it is worth emphasizing the role of the level and pace of economic development and to what extent they have a moderating or intermediary influence on the variables selected for the study. The role of the level of remuneration in relation to the income from selfemployment is also important.

Enterprises should pay increasing attention to the micro-environment and regional conditions, because the enterprise depends on these conditions and may affect many of them.

Generally, it might be worth considering more in-depth research concerning the factors affecting the degree of entrepreneurship in border areas based on an extensive survey among entrepreneurs operating there.. Such a survey would enable isolating the most important factors affecting entrepreneurship in the examined group.

\section{References}

Ahmed, Y. H., Ahmed E-S. A., \& Mohamed A. R. (2014) New GMM Estimators for Dynamic Panel Data Models. International Journal of Innovative Research in Science, Engineering and Technology, Vol. 3, No. 10 (October 2014), 1641416425, DOI: 10.15680/IJIRSET.2014.0310003.

Audretsch, D. B., Carree M.A., Stel van A.J., \& Thurik A. R. (2002) Impeded industrial restructuring: the growth penalty, Kyklos, Vol. 55, pp. 81-98, doi. org/10.1111/1467-6435.00178.

Audretsch, D.B., Thurik A. R. (2000) Capitalism and democracy in the 21st century: from the managed to the entrepreneurial economy. Journal of Evolutionary Economics, 10 (1), pp. 17-34, DOI: 10.1007/s001910050003.

Audretsch, D.B., Thurik A. R. (2001). What is new about the new economy: sources of growth in the managed and entrepreneurial economies. Industrial and Corporate Change, Vol. 10, No. 1, pp. 25-48, doi.org/10.1093/icc/10.1.267.

Audretsch, D. B., Carree M.A., \& Thurik A. R. (2002). Does entrepreneurship reduce unemployment? Tinbergen Institute Discussion Paper, TI 2001-074/3, Erasmus University Rotterdam. 
Audretsch, D.B., Thurik A. R., Verheul I., \& Wennekers S. (2002) Entrepreneurship: Determinants and policy in a European - U.S. comparison, Kluwer Academic Publishers, 2-44.

Audretsch, D.B., Thurik A.R. (2004) The model of the entrepreneurial economy. International Journal of Entrepreneurship Education, 2(2), 143-166.

Baltagi, B.H. (2005) Econometric Analysis of Panel Data, John Wiley\&Sons, Ltd., Chichester, West Sussex, 2-9.

Bond, S. (2002) Dynamic panel data models: a guide to micro data methods and practice, Cemmap, 22-24.

Brañas-Garza, P., Bucheli M., Garcia-Muñoz T. (2011) Dynamic panel data: A useful technique in experiments. Department of Economic Theory and Economic History of the University of Granada, ThE Papers 10/22, 3-11.

Brock, W.A., Evans D.S. (1989) Small Business Economics. Small Business Economics, 1(1), 7-2.

Bun, M. J.G., Sarafidis, V., (2013) Dynamic Panel Data Models. UvA Econometrics Working Papers 13-01, Universiteit van Amsterdam, Dept. of Econometrics, 3-5.

Burzyńska, D., Jabłońska M., Dziuba R. (2018) Opportunities and Conditions for the Development of Green Entrepreneurship in the Polish Textile Sector, Fibres \& Textiles in Eastern Europe, No 2 (128), 14, DOI 10.5604/01.3001.0011.5733.

Carree, M.A., Thurik A.R. (1999) Industrial structure and economic growth, in: D.B.Audretsch and A. R. Thurik (eds.) Innovation, Industry Evolution and Employment, Cambridge, UK: Cambridge University Press, 86-110.

Carree, M.A., Stel van A.J., Thurik A.R., \& Wennekers A.R.M.(2002) Economic development and business ownership: an analysis using data of 23 OECD countries in the period 1976-1996. Small Business Economics, 19, 271-290, DOI: $10.1023 / \mathrm{A}: 1019604426387$.

Carree, M.A. and Thurik A. R. (2003) The impact of entrepreneurship on economic growth', in D.B. Audretsch and Z.J. Acs (eds), Handbook of Entrepreneurship Research, Boston/Dordrecht: Kluwer Academic Publishers, 437-471.

Carter, N., Gartner, W., Shaver, K., \& Gatewood, E. (2003) The career reasons of nascent entrepreneurs. Journal of Business Venturing, 18(2003), 13-39, DOI: 10.1016/S0883-9026(02)00078-2.

Curtin, R. T. Reynolds, P.D. (2018) Panel Study of Entrepreneurial Dynamics, PSED II, United States, 2005-2011, Ann Arbor, MI: Inter-university Consortium for Political and Social Research, https://doi.org/10.3886/ICPSR37202.v1.

Davidsson, P. (2003) The Domain of Entrepreneurship Research. Some Suggestions. Advances in Entrepreneurship, Firm Emergence, 315-372, DOI: 10.1016/ S1074-7540(03)06010-0.

Davidsson, P, Steffens, P, \& Gordon, S. (2011) Comprehensive Australian Study of Entrepreneurial Emergence (CAUSEE): design, data collection and descriptive 
results. Handbook of Research on New Venture Creation, 216-250, DOI: 10.1007/978-1-4419-7536-2_2.

Dees J.G. (1998) The Meaning of Social Entrepreneurship, Stanford University, $1-5$.

Dziuba, R. (2014). Rola innowacyjności i konkurencyjności w rozwoju regionu Bałkanów Zachodnich na przykładzie Czarnogóry, in: Studia i Prace Wydziału Nauk Ekonomicznych i Zarzadzania, Wydawnictwo Naukowe Uniwersytetu Szczecińskiego, No 37/2, 221-230.

European Commission (2000) The European Observatory for SME- Sixth report, submitted to the Enterprise Directorate General by KPMG Consulting, EIM Business and Policy Research, and ENSR, Luxembourg, 35-86.

European Innovation Scoreboard ( 2017) European Union 2017, 6.

Faris, S. (1999) Seeking Entrepreneurial Origins: Are Entrepreneurs Born or Made? Kaufmann Center for Entrepreneurial Leadership, Kansas City. 1-3.

Gartner, W.B. (1988) Who is an Entrepreneur? is the Wrong Question. American Journal of Small Business, 13/1988, 11-32.

Gartner, W., Shaver, K., Carter, N., \& Reynolds, P. (2004) Handbook of Entrepreneurial Dynamics: The Process of Organizational Creation. Thousand Oaks, CA: Sage Publications, DOI: 10.4135/9781452204543.

Gatewood, E., Shaver, K., \& Gartner, W. (1995) A longitudinal study of cognitive factors influencing start-up behaviors and success at venture creation. Journal of Business Venturing, 10(5), 371-391, DOI: 10.1016/0883-9026(95)00035-7.

Gries, T., Naude W. (2009) Entrepreneurship and regional economic growth: towards a general theory of start-ups, Innovation. The European Journal of Social Science Research, Vol. 22, No. 3, 309-328, doi.org/10.1080/ 13511610903354877.

Grilo, I., Thurik R. (2004) Determinants of Entrepreneurship in Europe. ERIM Report Series Reference No. ERS-2004-106-ORG. 2-8.

Hébert, R.F., Link A.N. (1989) In search of the meaning of entrepreneurship. Small Business Economics, 1 (1), 39-49.

Hills, G.E., Lumpkin G.T., \& Singh R.P. (1997) Opportunity Recognition: Perceptions and Behaviors of Entrepreneurs. Frontiers of Entrepreneurship Research, Babson College, Wellesley, 203-218.

Jabłońska, M., Stawska J., Czechowska D.I. (2019) Country - specific determinants of textile industry development in Poland: comparative analysis of the years 2007 and 2017, Autex Research Journal, p. 7, Available at: https://content. sciendo.com/view/journals/aut/ahead-of-print/article-10.2478-aut-2019-0064. xml (access: 21.02.2020).

Leković, B., Berber N. (2019) Determinants of early stage high-growth entrepreneurship: Evidence from south east Europe region. Journal of East 
European Management Studies, Vol. 24, No. 2, 347-369, DOI: 10.5771/09496181-2019-2-347.

Liao, J, Welsch, H, \& Tan, W. (2005) Venture gestation paths of nascent entrepreneurs: Exploring the temporal patterns. The Journal of High Technology Management Research, 16(1), 1-22, DOI: 0.1016/j.hitech.2005.06.001

Minniti, M. (1999). Global Entrepreneurship Monitor. National Entrepreneurship Assessment: Italy. Executive Report, Babson College, Wellesley, 24.

Meyer, N., Meyer, D. F. (2017) An Econometric Analysis of Entrepreneurial Activity, Economic Growth and Employment: The Case of the BRICS countries, International Journal of Economic Perspectives, Vol. 11, No. 2, 429441.

OECD. (2000) OECD Employment Outlook, Paris: OECD, 155.

OECD. (1998) Fostering Entrepreneurship, the OECD jobs strategy, Paris: OECD.

Praag, M.C. van. (1999) Some classic views on entrepreneurship. De Economist, 147 (3), 311-335.

Reynolds, P.D., Hay M., Bygrave W.D., Camp S.M. \& Autio E. (2000) Global Entrepreneurship Monitor: 2000 Executive Report. Kauffman Centre for Entrepeneurial Leadership at the Ewing Marion Kauffman Foundation, 16-30.

Sechster Periodischer Bericht uber die Regionen: Zusammenfassung der Hauptergebnisse (1999) Regionalpolitik und Kohasion, Europaische Union, Brussel, 2-20.

Wlaczak D., Zołączkiewicz A. (2015) Selected determinants of entrepreneurship development in Poland, Roczniki Naukowe, tom XVII, nr 3, Stowarzyszenie Ekonomistów Rolnictwa i Agrobiznesu, Poznań, 49-67, DOI 10.7172/16449584.62.4.

Wennekers, A.R.M., Thurik A.R. (1999) Linking entrepreneurship and economic growth. Small Business Economics, No 13 (1), 27-55.

Zoltan, J. Acs., Audretsch D.B., Braunerhjelm P., Carlsson B. (2012) Growth and entrepreneurship. Small Business Economics, Vol. 39, No. 2, pp. 289-300, DOI: 10.1007/s11187-010-9307-2. 


\title{
Ključni čimbenici koji utječu na poduzetništvo: komparativna analiza
}

\author{
Małgorzata Jabłońska1, Joanna Stawska ${ }^{2}$
}

\begin{abstract}
Sažetak
Svrha ovog rada je identificirati čimbenike koji određuju stopu rasta poduzetništva u odabranim regijama Poljske i Češke, dviju susjednih zemalja u period od 2007. do 2017.godine. To razdoblje uključuje vrijeme financijske i ekonomske krize, koja je u različitim omjerima mogla utjecati na odrednice poduzetništva u različitim regijama. Diferencijacija odabranih varijabli $i$ njihovog utjecaja na stopu poduzetništva temelji se na mnogim elementima. Da bi se postigao postavljeni cilj, primjenjene su sljedeće istraživačke metode: prezentacija statističkih podataka, statistička i ekonometrijska metoda istraživanja - logaritamski panel model s vremenskom odgodom. U radu se također ističe važnost poduzetništva za gospodarski razvoj zemlje. S obzirom na visoki stupanj konkurentnosti na lokalnom i globalnom tržištu, poduzeća bi trebala posvetiti sve veću pozornost mikrookruženju i nekim regionalnim uvjetima, jer poduzeće ovisi o tim uvjetima i može utjecati na mnoga od njih.Rezultati istraživanja, a time $i$ doprinos $i$ njihova dodana vrijednost, su sljedeći: porast lokalnog poduzetništva pozitivno se prenosi na rast međunarodnog poduzetništva, dok su ulaganja za istraživanje i razvoj $i$ prosječne naknade u gospodarstvu ključni čimbenici koji utječu na razvoj poduzetništva.
\end{abstract}

Ključne riječi: poduzetništvo, MSP, financije, regionalni razvoj

JEL klasifikacija: R11, R12, F65, M13, L26

1 Doktor ekonomskih znanosti, Department of Finance and Accounting of SMEs, Faculty of Economics and Sociology, University of Lodz, Rewolucji Street, No 39, 91-214 Lodz, Poljska. Znanstveni interes: poduzetništvo, financijske odrednice poduzetništva, mala i srednja poduzeća. E-mail: malgorzata.jablonska@uni.lodz.pl.ORCID 0000-0003-1465-8818.

2 Doktor ekonomskih znanosti, Department of Central Banking and Financial Intermediation, Faculty of Economics and Sociology University of Lodz, University of Lodz, Rewolucji Street, No 39, 91-214 Lodz, Poljska. Znanstveni interes: financije poduzeća, monetarna i fiskalna politika.E-mail: joanna.stawska@uni.lodz.pl.ORCID 0000-0001-6863-1210. 